\title{
Carnistic Colonialism: A Rhetorical Dissection of "Bushmeat" in the 2014 Ebola Outbreak
}

\author{
S. Marek Muller* \\ School of Communication and Multimedia Studies, Florida Atlantic University, Boca Raton, FL, United States
}

This article argues that a fusion of critical animal studies and postcolonial critique affords food systems scholars a richer understanding of Western media narratives regarding a "bushmeat problem" during the 2014 Ebola outbreak. To do so, I perform a rhetorical analysis of expert, journalistic, and editorial texts disseminated through outlets with high economic and/or social capital in North American and Western European countries. My analysis demonstrates three overarching themes in these texts regarding the intersections of bushmeat and Ebola, which I describe as: 1) biosecurity; 2) conservation; and 3) development. By invoking an ethic of anti-speciesism and decoloniality, I not only demonstrate the colonial logics at play in the 2014 Ebola outbreak, but also name an

OPEN ACCESS

Edited by:

Kathleen P. Hunt,

SUNY New Paltz, United States

Reviewed by:

Jennifer Peeples,

Utah State University, United States

Sibo Chen,

Ryerson University, Canada

*Correspondence:

S. Marek Muller

mullers@fau.edu

Specialty section:

This article was submitted to

Science and Environmental

Communication,

a section of the journal

Frontiers in Communication

Received: 20 January 2021 Accepted: 05 May 2021

Published: 21 May 2021

Citation:

Muller SM (2021) Carnistic

Colonialism: A Rhetorical Dissection of

"Bushmeat" in the 2014

Ebola Outbreak.

Front. Commun. 6:656431.

doi: 10.3389/fcomm.2021.656431 insidious ideology fundamental to food systems discourse in postcolonial contexts: carnistic colonialism.

Keywords: Ebola, bushmeat, critical animal studies, postcolonial, carnism, rhetoric

\section{INTRODUCTION}

In 2014, West Africa experienced an outbreak of the deadly Ebola Virus Disease, colloquially shortened to its filovirus strain, Ebola. It was both the first outbreak recorded in the region and the largest recorded outbreak on record. Ebola-a viral, contagious, and hemorrhagic disease infamous for its high mortality rate of between 25 and 90 percent-was an epidemiological rarity. Whereas occasional outbreaks were usually isolated, this one was unusually widespread, crossing city and country borders. Guinea reported its first suspected case in March 2014. By the end of the month, Liberia had multiple suspected infections. By May, Sierra Leone did too. Ebola spread so rapidly that the outbreak dominated news headlines from 2014 to the summer of 2015, when the virus seemed more-or-less "contained." The World Health Organization (WHO) did not remove West Africa's Ebola crisis from its list of Public Health Emergencies of International Concern until March of 2016. By then, 28,616 confirmed, probable, and suspected cases of Ebola had been reported, with 11,310 resulting in death (World Health Organization, 2016). According to the WHO, West Africa's 2014-2016 outbreak was "the largest and most complex Ebola outbreak since the virus was first discovered in 1976" (World Health Organization, 2021).

While 99\% of all reported cases were confined to Guinea, Liberia, and Sierra Leone, 2014-2015 transnational media discourses circulated the voices of rhetorical stakeholders concerned about the spread of a global, apocalyptic Ebola pandemic (Benton and Dionne, 2015). WHO Director-General Margaret Chan framed the frightening state of affairs as the "most severe acute public health emergency in modern times" (qtd. in Wilkinson and Leach, 2015, p. 136). Chan was one of many narrators, ranging from government officials to public health professionals to ideological 
editorialists, fixated on the contagiousness of Ebola and its risk to publics residing outside of Sierra Leone, Liberal, and Guinea-or, more specifically, in "The West."

Such responses are unsurprising, as epidemics like Ebola are both medical and cultural phenomena. Diseases "bring into focus the concerns we have about the way we live our lives, our relations to community, environment, and cosmos, and they challenge us to explain the purpose of malfunction and suffering" (Anderson, 1999, p. 49) Perceptions of contagious epidemics often prompt searches for attributable "culprits" responsible for the outbreak. However, blaming specific parties for disease outbreaks all-toofrequently involves racialized rhetoric and ethnonationalist impulses (Huff and Winnebah, 2015). These impulses work in tandem to perpetuate a historical narrative embedded in Western European and U.S. American expansionism and colonialism "permitting the stereotyping of foreigners, the poor, and other races, as inherently disease-dealing and polluting" (Anderson, 1999, p. 49).

As a result, sociopolitical and mediated responses to exigent contagious diseases amplify stories of "zoonotic spillover events" wherein pathogens jump from insect to animal, from animal to human, from individual to community, etc. (Huff and Winnebah, 2015). Early international media coverage of the 2014 Ebola outbreak employed this prototypical "outbreak narrative," while searching for "patient zero," that human who had first contracted the virus and spread it outward (Huff and Winnebah, 2015; Hasian, 2016). This outbreak, it was concluded, started in small village of Miandou, Guinea, where two-year-old Emile Ouamouno was infected by a wild bat. Ouamouno likely handled fruit pre-contaminated by the bat, played too near a bat colony, or ate the bat itself. Despite unclear evidence, international media (particularly those geared toward U.S. American and Western European audiences) latched onto this third option: the child's possible consumption of contaminated, non-domesticated bat flesh.

To this day, precise details about the "ecology of Ebola" and the particular "circumstances that led to the [2014] outbreak" remain somewhat uncertain (Huff and Winnebah, 2015, p. 2). Multiple vectors of disease were possible and likely occurred in tandem. However, an outbreak narrative specifically centering African bushmeat consumption flourished throughout the 2014 Ebola outbreak and beyond. According to McGovern (2014), the rhetorical format of the Ebola outbreak had a distinctive formula: "Ebola is contained in exotic animals + West Africans eat these animals $=$ a pandemic that kills its victims by causing their internal organs to liquefy" (para. 3). However, according to Wilkinson and Leach (2015), pinning blame on rural African populations' bushmeat diet and narrating it as the "official truth" regarding the Ebola outbreak amounted to mere "misguided exhortations" that "have contributed to the deluge of misinformation that has undermined local trust in what officials say about Ebola" (p. 144-145). Disseminating an outbreak narrative emphasizing bushmeat and bushmeat-eaters as the culprits behind the Ebola epidemic was not only inaccurate, but also "distract [ing] us from asking deeper questions about the complex ecological and sociopolitical dynamics" that allowed the Ebola virus to reach epidemic proportions (Huff and Winnebah, 2015, p. 2).
Materially, bushmeat ranges from the killed and cooked flesh of "wild" animals ranging from bats to birds to apes, although smaller fauna like reptiles and rodents are more commonly consumed than charismatic megafauna (Vander Velde, 2014). Rhetorically, however, the term bushmeat is both a symbolic stand-in for an animal's consumable corpse and a discursive reflector of foreign and unfamiliar meat consumption practices, often from a Western gaze. Citizens of so-called "developing" nations have long hunted and consume "wild" animals not typically understood as "food animals" in the Western world. For this reason, Huff and Winnebah (2015) described the prototypical outbreak narrative as one that tells the very partial, very incomplete story of contaminated consumption. It is a tale, devoid of colonial context, in which "to augment lean diets and leaner incomes, impoverished people encroach further and further into the once-pristine wilderness in search of wild sources of protein-bushmeat" (p. 1, emphasis mine).

I therefore argue that the rhetorical circulation of an African "bushmeat problem" is an incomplete portrayal of the 2014 spread of Ebola. It is also a glimpse into how hegemonic narratives regarding the construction/consumption of "food" and "meat" dictate public discourses and institutional responses to intermingling environmental, agricultural, and epidemiological catastrophes. The 2014 Ebola outbreak is thus a case study of how outbreak narratives centering Othered peoples' Othered meats employ carnist and colonizing masternarratives. These narratives pit a scientifically informed, hygienic West over an uneducated and unclean not-West. They indicate how contemporary colonial logics are embedded in discourses of flesh production and consumption. Among those discourses are all-too-familiar rhetorical constructions of food (particularly meat) that simultaneously justify colonialism, racism, and speciesism (see Harper, 2011; Belcourt, 2015; Kim, 2015; Ko and Ko, 2017; Montford and Taylor, 2020; among others).

To be clear, I do not suggest that circulating arguments centering bushmeat-as-threat carry no factual weight. Zoonotic diseases pose one of the largest existential risks of the modern era (Everard et al., 2020). Rampant deforestation and industrialization have brought insects and animals from the "wild" into closer proximity with human-centered spaces, resulting in rapid disease transferals. Hunting, cooking, selling, and consuming non-domesticated meats is intimately embedded in this process. Ebola is far from the only viral catastrophe borne at least partially from ecosystem degradation, and the current COVID-19 pandemic is no exception (Shepherd, 2020). Environmental communication scholarship must always grapple with the tension between symbolic constructions and the material world, and in the case of bushmeat, the material consequences of animal corpses through slaughter and human corpses through zoonoses is undeniable.

What I do argue, however, is that environmental communication scholars should be concerned about the problematics of environmental and agricultural reforms dependent upon colonizing understandings of what (or who) is "meat" and how/by whom that meat should be raised, killed, sold, and consumed. Raymie McKerrow explained that rhetoricians' obligation to counter "the excesses of a society's 
own enabling actions, its 'repressive tolerance'... that underwrites the continuation of social practices that ultimately are harmful to the community" (McKerrow, 1989, p. 108). I suggest that a fusion of critical animal studies and postcolonial critique affords scholars insight into the dissemination of bushmeat narratives in times of global crisis. While bushmeat was both a material reality and a rhetorical construction during the 2014 Ebola outbreak, I posit that bushmeat-as-cultural-symbol dramatically overthrew the actual material elements of nondomestic animal hunting practices-particularly due to the intersecting politics of species oppression, capitalistic food systems, and colonial impulses.

Using ideological rhetorical criticism as my guiding methodology, I assess a series of mass-circulated rhetorical texts pertinent to the rhetorical construction of bushmeat during the 2014 Ebola outbreak. Ultimately, I identify three textual thematics at play: those of biosecurity, conservation, and international development. Although these rhetorical frameworks are convincingly cloaked in humanitarian benevolence, they belie an insidious desire to maintain a Western, colonial, and hegemonic standard of carnism. By invoking ethics of anti-speciesism and decoloniality, I not only demonstrate the colonial logics at play in the 2014 Ebola outbreak, but also name an insidious ideology fundamental to food systems discourse in speciesist and postcolonial contexts: carnistic colonialism.

\section{CRITICAL ANIMAL STUDIES AND THE RHETORICAL CONSTRUCTION OF "MEAT"}

I argue that a fusion of critical animal studies and postcolonial critique affords scholars a richer understanding of Western media narratives regarding a "bushmeat problem" during the 2014 Ebola outbreak. Meat is not an apolitical subject. Rather, it is embedded in the same material and symbolic systems that perpetuate inequality across race, gender, class, and species lines. Rhetorical criticisms of the food production/ consumption practices and public health discourses during the 2014 Ebola outbreak are incomplete when terms like "food" are left un-interrogated and when "meat" is assumed to be a product of specific animals raised and killed in specific ways. This conclusion is especially apparent during viral outbreaks of deadly diseases, particularly zoonotic viruses. By arbitrarily constituting certain animals as edible/inedible, safe/diseased, and disposable/valuable. Ebola narratives further revealed the insidious rhetoric of carnism guiding reprobations of bushmeat - a discursive manifestation embedded in colonial logics that I dub carnistic colonialism.

I use critical animal studies as a theoretical framework through which to render visible the discursive interconnections of animal exploitation (including animal slaughter, consumption, etc.) and human oppression (including racism, colonialism, etc.). Critical animal studies is a prescriptive and telos-driven approach to scholarship that interrogates the interweavings of speciesism with social justice politics writ large (Best et al., 2007). Speciesism is an ideology of homo sapien supremacy in which dubious anthropocentric discourse is used to justify the use and abuse of nonhuman animal bodies for human profit and pleasure (Singer, 1975). In naming speciesism as a matrix of domination fundamental to human and nonhuman animal oppression, the field advocates for an ethic of "total liberation" (Nocella et al., 2015). This ethic demands that its adherents rhetorically center issues of equity and justice through "intersectional" (Crenshaw, 1990) and "more-than-human" (Abram, 1996) analyses-specifically, of how speciesism functions in tandem with racism, sexism, ableism, and other oppressive to promulgate oppressive ontologies and practices within and across species lines.

Plumwood (2002) asserted that "human relations to nature are not only ethical, but also political" (p. 13). To wit, critical animal studies is a praxis-centered mode of academic analysis that "puts into action the feminist insight that 'the personal is political' and examines the political contexts of dietary choices as well as strategic and operational choices in science and economics" (Gaard, 2002). Cartesian-inspired "dualisms" such as human/nature, human/animal, and domestic/wild dualisms are fundamental to critical animal studies analyses because of how they allow "the western construction of human identity as 'outside' nature" (Plumwood, 2002, p. 2). Those deemed closer to "nature"-by virtue of gender, race, species, etc.,-are justified as inferior and therefore oppress-able, existing amidst "a field of multiple exclusion and control ... casting sexual, racial, and ethnic difference as closer to the animal and the body construed as a sphere of inferiority" (p. 4). This binaristic model of subjectivity contributes to the maintenance of colonial logics by pitting the idealized Man against the animalistic less-than-human, or Not-Man (Ko and Ko, 2017; Wynter, 2003).

Understanding speciesism's role in the rhetorical construction of bushmeat during the 2014 Ebola outbreak necessitates defining another central term to critical animal studies: carnism. Coined by psychologist and animal rights activist Melanie Joy, the term refers to a hegemonic ideology in which the relentless consumption of animal flesh is presumed to be Natural, Normal, and Necessary. Joy (2011) argued that due to the diversification of food options and burgeoning of the vitamin industry in industrialized societies, hyper-capitalist food production and consumption discourses in the West prescribe industrialized meat consumption "not because we have to" but "because we choose to ... simply because it's what we've always done, and because we like the way we taste" (Joy, 2011, p. 21). A flesh-centered carnist ideology functions through invisibility, cloaking mass slaughter of conscious subjects in objectoriented terms like "meat," "beef," or "pork." Adherents pass legislation designed to keep mass publics from seeing the brutal practices that hyper-capitalist standards wreak on the agriculture industry. Invisibility allows meat consumption to be perceived as a baseline behavior as opposed to a choice, like ethical veganism-flesh consumption is, after all, "normal, natural, and necessary" (Joy, 2011, p. 96). Nonetheless, the "three N's" guiding carnism maintain ideologically-bound underpinnings wherein "eating certain animals is considered ethical and appropriate" (p. 22, emphasis mine). Those deviating from 
this carnist standard, either through eschewing animal products or eating the "wrong" meats, are named deviant.

Critical animal studies also concerns itself with the hegemonic ideologies and exploitative politics concerning nonhuman animal subjects' fleshy food-ness and edibility. Its critique of food production and consumption discourses thus recognizes that "food" and "meat" are metaphoric stand-in terms for specific sets of animals raised, slaughtered, and reproduced for mass consumption. These practices are naturalized, normalized, and necessitated through scientific and industrial discourses that eschew the subjectivity of "food animals" in favor of detached, abstract genres describing agricultural processes. Western-centric discourses of food production and consumption privilege specifically "domestic" animals and their products for ingestion, separating them from "wild" animals like chimpanzees or "vermin" like bats. In doing so, "Many environmentalists neglect that part of nature which is not 'green.' Domesticated animals ... long ago ceased to be fauna" (Adams, 1997, p. 38).

Thus, the carnist term "meat" calls for intensive interrogation as a "mass term deontologizes animals" (Adams, 1997, p. 35). A cow becomes "beef," a she becomes an "it," and a living being a mere product for human consumption. This strategic carnist discourse maintains the invisibility of the mass cruelty and deaths involved in the consumption of animal products by linguistically transforming the once-living beings into what Adams (1994) called "absent referents." Despite conceptions of domesticated "livestock" as natural foodstuffs in the Western world, even categories of what food "is"/"is not" rely not upon a "natural order," but rather social constructions and discursive categorization processes.

When carnist rhetoric manifests in moments of inter- and cross-cultural antagonism, it often takes on colonial tonality. The production and consumption of animal bodies is still constructed as "natural, normal, and necessary," but only under the appropriate, "civilized" circumstances. Constructions of consumability remain tied to sociocultural forces that, even in "post" colonial contexts, are embedded in colonial histories and discourses disdaining "the natives" as "filthy," as "savage," and as "cruel." Carnism is not merely carnism, but rather carnistic colonialism, an ideology and discourse of edibility that favors Western, industrialized, capitalistic modes of animal production and consumption situated within transnational histories of coloniality, heteropatriarchy, and white supremacy. Carnistic colonialism is, perhaps, even more insidious than traditional carnist discourse, as it cloaks itself in whitewashed neoliberal norms of health, diet, and agriculture.

To wit, critical animal studies' antispeciesist ethic is supplemented by a firm alliance with the field of postcolonial studies. Food and food systems are not immune from colonially carnistic politics. In fact, colonialism has been fundamental to the construction of contemporary industrialized agricultural systems. Ergo, in assessing the politics of carnistic colonialism in the 2014 Ebola outbreak, it is necessary to assess how cultural deviations from Western standards of meat production contributed to overblown fears of an African-borne global pandemic stemming from threatening terms like "bushmeat."
A postcolonial approach to anti-speciesism notes the distinctive responses to instances in which those species categorized as "non-food" are consumed by Othered peoples, as in the case of bushmeat (Bratanova et al., 2011). While critical animal studies emphasizes food de-familiarization and animal non-consumption as a praxis, it also invokes a nuanced animal liberation philosophy sometimes called "moral contextual vegetarianism" (Curtin, 1991). Real-life material circumstances do not tend to mesh with universal ethical frameworks. Particularly in rural societies with little other options for nutrition, slaughtering an animal for nutrients might not be in keeping with critical animal studies' vegan ideal, but can be understandable and/or appropriate for the sake of pragmatic survival. The anti-exploitation ethic of total liberation calls for the abandonment of animal consumption as far as is possible and practicable (Wright, 2017)-therefore, while it is not prima facie "wrong" to critique flesh-eating practices like bushmeat, an ethic of total liberation calls first for the individual's interrogation of their personal complicity with oppressive speciesist systems and the praxis-centered actions they can take themselves and in their own cultural communities for the sake of multispecies justice (Gaard, 2002; Kim, 2015).

A moral contextual, ethically integrative approach for postcolonial food politics allows for Western scholars/activists to take both inter- and cross-cultural approach to anti-speciesist, decolonial praxis wherein it is of less importance to condemn the consumption practices of "Others" than to reflect and condemn unsustainable agricultural practices in the Western world (Gaard, 2001). And, more pertinently to this essay, it further allows for a critique of those moments in which subjugated and/or lessresourced communities fight to have their resistive voices heard in "post" colonial, non-Western contexts (Hunt, 2014). Thus, the premier tasks of anti-speciesist rhetoricians raised and/ or residing in the West is to 1) critique the species "tokenism" of environmental thinkers that value certain charismatic megafauna over others and 2) to build inter- and cross-cultural ethics that deemphasize moralistic outsiders critiquing cultural contexts they know nothing about while empowering community insiders to "challenge oppression within the movements and the cultures of which we are a part" (Gaard, 2001, p. 21, emphasis mine).

A rhetorical interrogation of carnistic colonialism through the lens of critical animal studies thus helps explicate the hegemonic ideologies that guide global food cultures and thus justify judgments of those who do not adhere to those arbitrary constructs. Studying carnistic colonialism adds credence to Carol Adams' theory that during discussions of food contamination, "the anxiety cultural commentators observe is not about what goes into food, but what is food" (Adams, 2006, p. 27). Doing away with normative understandings of meat consumption is essential to defamiliarizing the concept of "meat" altogether, as well as the other "categories" of animality (vermin, wildlife, etc.) that are named as disgusting, diseased, and/or inedible. Understanding that animal flesh need not necessarily be a part of most $21^{\text {st }}$ century diets, rather than assuming that only "some" meats ought to be considered acceptable and "developed" cultural practices, renders 
unintelligible those colonial logics condemning bushmeat consumption in "underdeveloped" African countries. Investigating discourses surrounding the transnational, transhistorical politics of food production, and consumption thus reveals how carnistic colonialism constructs and maintain unsustainable visions of food and public health while furthering longstanding colonial logics constructing "the unsanitary native."

A rhetorical analysis of bushmeat from both an anti-speciesist and an anti-racist perspective calls thus for a decolonial ethic. This ethic is in keeping with the de- and postcolonial rhetorical scholarship produced in communication studies. Wanzer (2012) in particular noted how rhetoricians must practice "epistemic disobedience" in the pursuit of praxis that "de-links" the study of rhetoric from colonial ontologies. "Colonial" in this instance can be studied through what Quijano (2000) dubbed the "coloniality of power," referring to the ordering and classification of the world via a process of racialization and the construction of difference via systems of knowledge, hierarchies, and culture. De-linking from master discourses normalizing such power relations must invoke an ethic of decolonization:

The energy that does not allow the operation of the logic of coloniality nor believes the fairy tales of the rhetoric of modernity ... decolonial thinking is, then, thinking that de-links and opens ... to the possibilities hidden" (Mignolo, 2011, p. 46).

Studying Ebola discourses from a decolonial perspective thus enacts a telos through which scholars "think of new ways of raising consciousness about political problems, so that scholars can combat the pernicious effects of what Spivak has called the "social textuality" of colonialism" (Hasian, 2001, pp. 23-26). Since, as Sastry and Dutta (2017) insisted, the cultural dynamics of infectious disease pandemics influenced the resultant development of mass-disseminated ontological Ebola narratives, analyzing the discourses of 2014 Ebola outbreak necessitates understanding the embeddedness of colonial logics guiding cross-cultural interactions with "tropical" and "wild" lands. The intersections between colonial logic, food cultures, and global public health rhetorics are made manifest through postcolonial critique and decolonial ethics. Pointing out such connections resists contemporary manifestations of what Shome and Hegde (2002) dubbed "the discrete positioning of cultures without any sense of their interconnected histories" that "reproduces the violence of colonial modernities and fixes difference in a spectacle of otherness" (p. 263).

The history of medicine is hardly apolitical, particularly as scientific and medical knowledge manifested themselves in European colonies. And the history of Western colonization is incomplete without studies of how colonial medicine functioned "within an expansive ideological order of the empires, linked to the economic interests of the colonizers" (Davidovitch and Zalashik, 2006, p. 309). Colonial applications of medicine both as potential cures for disease and part of a colonial logic in which medicinal rhetoric produced "borders and distinctions between colonizers and colonized bodies as well as between Western knowledge and traditional local knowledge" (p. 309). Colonies in Africa and South Asia had environments teeming with new flora, fauna, bacteria, pathogens, and disease when Western colonists sought to settle their empires. To prevent their own deaths, colonists "called for massive, ceaseless disinfection" (Anderson, 1995, p. 641). The disinfecting process would involve human and animal bodies, often at the same time. Policies could involve culling particular species en masse, as occurred in German scientist/colonist Robert Koch's 1906 "war on crocodiles" - a confounding attempt to rid East Africa of the animals he believed to be the primary vectors of sleeping sickness.

Central to the colonizing mission "was to examine systematically the whole population ... and to reform its customs and habits ... an instance of a material power that operates on distinctly racial bodies to produce the sort of body that colonial society required" (p. 645). Warwick Anderson's research on the colonized Philippines presented the arguments that "bodies that polluted [the environment] required control and medical reformation; and the vulnerable, formalized bodies of the American colonialists demanded sanitary quarantine" (Anderson, 1995, p. 641). Despite applications of (in)voluntary vaccinations, "the more effectively vaccination intervenes, the less useful it is as a vehicle for social discipline" (p. 19). Of equal importance was doing away with cultural arenas like "the marketplace," where bushmeat was available. Colonial diplomat Nicholas Roosevelt remarked that at such markets, "many varieties of intestinal germs and parasites may lurk in most foods," and Daniel R. Williams, a member of the U.S. Philippine Commission, remarked that native marketplaces were "unwholesome and death-dealing plazas" (qtd. in Anderson, 1995, p. 656).

The 2014 Ebola outbreak is a rich case study in the longstanding and ongoing rhetoric of carnistic colonialism. To wit, in the following sections, I demonstrate how contemporary medical discourses surrounding the 2014 Ebola epidemic followed a familiar discursive pattern in which both "nature" and "natives" were presented as unclean, uneducated, and immoral, and thus in need of moral (and not necessarily medical) interventions.

\section{IDEOLOGY AS RHETORICAL METHODOLOGY}

The following analysis utilizes a very specific type of rhetorical criticism: ideological rhetorical criticism. Performing rhetorical critique means engaging with how a rhetor's various communication practices influence their audience to induce an action or orientation toward the world. By assessing the macroand micro-elements of an argument's structure (called by various names, including "rhetorical fragments," "symbols," "ideographs," etc.) rhetoricians identify effective and/or fallacious elements of discourse that succeed and/or fail to produce a desired behavior. For the purpose of this study, ideology can be defined as "a political language, preserved in rhetorical documents, with the capacity to dictate decision and control public belief and behavior" (McGee, 1980, pp. 3-4). Ideological rhetorical critique is a descriptive and prescriptive approach to scholarship that is embedded in critical theory and critical performance (see: McGee, 1980; Wander, 1984). It is a 
way to operationalize "critical rhetoric," which emphasizes the interconnections of language, knowledge, and power. Ideological rhetorical critique calls upon the rhetorician to "reconstruct" a series of argumentative fragments and put forward their interpretation(s) of this collection (see McKerrow 1989). In doing so, the critic reveals dominant and/or hegemonic ideologies implicit in the text as manifested through a rhetor's discourse (or their non-discourse). According to Marouf Hasian and S. Marek Muller, rhetorical contextualization via ideological critique:

demands that we consider the "I" (who the author is and is not), the text (what it did and did not say), the audience (who was and was not addressed), the problems (what was and was not mentioned/defined), and the solutions (what was and what not offered, and to whom) (Hasian and Muller, 2016, p. 5)

Essentially, ideological criticism names ideologies as "fundamentally rhetorical creations" (Hasian and Muller, 2016, p. 5).

In keeping with the premise of ideological rhetorical criticism, I conducted this study by systematically analyzing discrete units of analysis via a process of purposive sampling (Hasian and Muller, 2016). This mode of non-probablistic sampling relies on the critic's disciplinary judgment and prior subject-area expertise when choosing members of the broader human population to emphasize in their study. A rhetorician utilizes purposive sampling for ideological critique in order to access a particular discursive profile. Therefore, for this study, I collected a series of rhetorical texts that I believed most relevant to elucidating a specific phenomenon.

For this analysis, I chose texts that I deemed most suitable to addressing dominant and/or hegemonic ideologies guiding Western constructions of bushmeat in the 2014 Ebola outbreak. I specifically chose written texts that were available in an online format, that did not require a paid subscription to view, and that were authored by individuals and/or organizations with a wide viewer base. I did so in order to ensure that the texts I studied were more likely than others to reach large segments of the English-speaking population (since, while "the West" is composed of multiple North American and European countries, English is a primary or secondary language of most of these places).

The texts that I sampled came in three genres: expert, journalistic, and partisan. "Expert" texts were defined as pamphlets, essays, and other written discourse authored by those with advanced degrees and professional careers in public health, conservation, etc. "Journalistic" texts were defined as informative and non-editorialized pieces published in professional news media outlets. "Partisan" texts were defined as editorial and/or opinion pieces published in overtly left- or right-leaning outlets meant to both inform and sway audience toward some political and/or social goal. Furthermore, of the English-language texts I sampled, I chose authors, organizations, and/or outlets publically understood to be "known names" in their respective fields (for example, the Center for Disease Control for experts in public health, Newsweek for Englishlanguage journalism, or One Green Planet for left-leaning environmental advocacy). In summary, through a purposive sampling of over 30 online texts disseminated by expert, journalist, and partisan rhetors, I conducted an ideological rhetorical criticism of "bushmeat" discourse during the 2014 Ebola outbreak. The results that follow contain quotes and examples most representative of the three themes I identified in this discourse.

\section{MAPPING CARNISTIC COLONIALISM IN EBOLA DISCOURSES ABOUT BUSHMEAT}

My analysis of the 2014 Ebola outbreak reveals three thematic discourses used by Western authors to condemn bushmeat consumption in Africa, usually to other Western audiences: biosecurity, conservation, and development. Despite their veneers of objectivity, a rhetorical critique of these texts reveals colonial, carnist conceptions of civilized food practices (specifically, civilized flesh-eating practices) in a globalizing world. An ethic and discourse of carnistic colonialism guided anti-bushmeat discourses during the 2014 Ebola outbreak.

\section{Biosecurity}

The first emergent discourse regarding the 2014 Ebola outbreak's "bushmeat problem" centered biosecurity. Specifically, rhetors warned that if the bushmeat trade was not curbed, Ebola could spread beyond West Africa and into other, specifically North American and Western European, countries. An August 2014 issue of Newsweek garnered controversy with its article "Smuggled Bushmeat is Ebola's Back Door to America." The authors described an America besieged with contaminated immigrant communities complicit in the Ebola pandemic:

Less than three miles from Yankee Stadium, the colorful storefronts of African markets lining the Grand Concourse are some of the first signs of a bustling Bronx community that includes immigrants from those West African nations hit hardest by the recent and unprecedented outbreak of the Ebola virus ... A turbaned woman smiles vividly when we enter one small market with canned goods displayed in its window, but the light in her eyes immediately dims when we ask about bushmeat. Shrugging, looking away, she says she knows nothing about it and then, after a moment's calculation, asks us to repeat the word, as if she didn't understand what we had said. (Flynn and Scutti, 2014, para. 1-2).

The article emphasized African immigrants' love for bush rats and guinea pig meat "despite the fact that it is illegal in the U.S. (para. 6). Noting that immigrants might pay $\$ 100$ for a slab of bushmeat, they analogized the trade as "a luxury indulgence in the same way illegally imported caviar might for Russian émigrés in Brooklyn" (para. 6). Increased immigration, they reported, led to an increase in illegal bushmeat in America, despite the meats' "deadly threat" to Americans via Ebola, SARS, Monkeypox, and even HIV, which was "almost certainly transferred from bushmeat" (para. 33). True, U.S. medical personnel had yet to find any Ebola pathogens in confiscated bushmeat, but "they only tested a few samples" (para. 26). 
Immigrants could and would continue smuggling to enjoy a meal that has "just barely processed in order to keep it from rotting" (para. 27).

Some outlets blamed lack of governmental oversight for overseas bushmeat trades. Prior to the 2014 epidemic, Food Safety News reported on a smaller Ebola outbreak, commenting "In the U.S., all store-bought meat comes from regulated, government-inspected slaughter facilities. There are rules ... But when it comes to African bushmeat, all bets are off" (Richardson, 2012, para. 3). Indeed, "Poachers' wire snares catch animals indiscriminately, without regard to the species snared or the health of the individual animal caught" (para. 3). This discourse continued into 2014-15, with many rhetors commenting that, while those handling the raw bodies of bushmeat animals bore the greatest risk of contracting zoonotic diseases, consuming cooked bushmeat was still a concerning disease vector. $B B C$ acknowledged that the actual risk of contracting Ebola from an improperly cooked animal corpse was low: "The estimate of more than 100,000 bats consumed has not resulted in a single case of Ebola in Ghana" (Hogenboom, 2014, para. 22). Nonetheless, Newsweek maintained that despite African immigrants' traditional pathogen-containing methods via smoking and drying the bushmeat, "bushmeat may appear safe, but the flesh inside is still juicy-filled with blood, fresh tissue and more" (Flynn and Scotti, 2014, para. 26).

Still others-particularly medical experts and scientific institutions-attributed bushmeat's biosecurity risks to African immigrants' naiveté. Dr. Marcus Rowcliffe told $B B C$ : "People who eat bat bushmeat are rarely aware of any potential risk associated with consumption. They tend to see it as healthy food" (qtd. in Hogenboom, 2014, para. 21). Dr. George Amato of the American for Museum of Natural History concurred with this thesis, complaining to Newsweek about bushmeat the relationship between meat smoking and smuggling: "If you wanted to safely transport meat and not worry about pathogens, you wouldn't smoke it. It's not a very efficient way of killing microorganisms." (Flynn and Scutti, 2014, para. 27). Further, the Center for Disease Control (CDC) composed a one-pager on bushmeat avoidance, instructing educated U.S. immigrants to "Tell friends and family to avoid African bushmeat because it is illegal to bring it into the United States and can make people sick" (CDC, 2014, para. 5). Granted, it acknowledged, "there have been no reports of human sickness in the United States from preparing or consuming bushmeat illegally brought into the United States" (para. 3). The WHO further warned that "The initial source of past EVD outbreaks was likely human contact with wild animals through hunting, butchering and preparing meat from infected wild animals ("bush meat")" while immediately adding that "in the current outbreak, the majority of cases are a result of human to human transmission" and that "If food products are properly prepared and cooked, humans cannot become infected by consuming them: the Ebola virus is inactivated through cooking." (World Health Organization, 2014). Editorial appropriated and elaborated upon these expert discourses to their political advantage, with the conservative Breitbart reporting that "The refusal to believe bush meat is unsafe is partly due to a belief that Ebola was caused by medical workers to harvest organs from African villagers" (Chastain, 2014, para. 7).

However, these biosecurity discourses conveniently ignored institutional practices and material realities that, when identified, call into question the legitimacy of the enthymematic linkage between the spread of Ebola and the consumption of bushmeat. Consider, for instance, the myth of the sanitary Western healthcare professional as antithesis to hysterical African vectors. Condit (2015) noted how rhetoric itself did not infect and kill people with Ebola pathogens, but "a specific rhetoric employed by the World Health Organization impeded the containment of the epidemic because it coded medical personnel as expert saviors rather than as vectors of the disease" (Condit, 2015, p. 121).

Experts, journalists, and partisans were sometimes so concerned with preventing unclean Africans and their food from moving beyond their borders that they overlooked how anyone contact with Ebola patients-even a Western medical doctor-could contract and spread the disease. By October of 2014, more than 500 African and non-African medical professionals contracted Ebola, and half died. Yet, health care workers continued receiving special exemptions from surveillance procedures: "their role as vectors was papered over by scientific literature, and they were depicted by WHO's public rhetoric as victims of an irrational public" (p. 122). Condit's analysis demonstrated that, while biosecurity discourses identified African natives and immigrants as premier vectors for an Ebola pandemic, they rendered invisible medical professionals' equal and often increased potential for spreading Ebola transnationally.

Anti-bushmeat biosecurity discourses also papered over the inherent "diseased-ness" of normalized Western meats-for instance, prototypical processes of industrial agriculture such as genetic engineering, overuse of antibiotics, and intensive confinement. Contemporary applications of genetic engineering in industrialized agriculture diminishes species biodiversity. In so doing, it fuels zoonotic pathogen adaptation and undermines animals' immunocompetence. Fowl, pigs, and cattle currently demonstrate increased disease susceptibility, an alarming discovery considering " $73 \%$ of emerging and reemerging human pathogens are zoonotic in origin" (Greger, 2011, p. 2). To deal with decreased immunocompetence, some agriculturalists pump their animals with antibiotics. This controversial veterinary practice significantly threatens human health "as pathogenic-resistant organisms propagated in these livestock are poised to enter the food supply and could be widely disseminated in food products" (Landers, et al., 2012, p. 5). Furthermore, exhaustive production methods like intensive confinement results in intense physiological change in animals that compromises their immune systems (Hinchliffe, et al., 2013). Indeed, "The high population density of modern intensively managed livestock operations results in sharing of both commensal flora and pathogens, which can be conducive to rapid dissemination of infectious agents" (Landers, et al., 2012, p. 5). Humans risk contracting Campylobacter, Salmonella, E-Coli, influenza, and other potentially deadly illnesses from confined livestock animals. 
Poor regulation of meat quality leads to outbreaks of painful and frequently fatal illnesses. Despite some rhetors' insistence that Western meat was somehow more edible due to better quality control, "controversies [rage] about the failures of the regulatory system in detecting new pathogens" (Collier and Lakoff, 2008, p. 11). USDA regulatory standards are so low that in many cases slaughterhouses are left to police themselves: "Carcasses have been considered acceptable for human consumption even when they've contained blood clots, stains, scar tissue from ulcers, liver spots, and hemorrhages" (Joy, 2011, p. 77). Indeed, "We have left the fox to guard the chicken coop. And not surprisingly, we have ended up with shit in our meat" (p. 79).

By ignoring these common disease vectors, mediated rhetors erroneously pathologized African people and their "unregulated" meats as substantially more dangerous than common, largerscale Western practices. Doing so rendered invisible the "troubling growth of "modernization risks" that are produced by institutions meant to promote health, security, and prosperity" (Collier and Lakoff, 2008, p. 8). Thus, the biosecurity trope amplified bushmeat's comparatively miniscule risk of transnational pathogenicity in favor of colonial and carnist standards of (un) sanitary consumption and agricultural (under) regulation.

\section{Conservation}

The second emergent discourse strand in the 2014 Ebola epidemic related bushmeat and Ebola to larger African conservation issues. Many Ebola-centered environmentalist rhetors applauded increased scrutiny of the bushmeat trade as Ebola's "silver lining" (Williams, 2014). For instance, New Scientist published that "We all hope this epidemic can be contained soon. But will we learn to change the behaviours that directly brought it about?" (Williams, 2014, para. 2). Calling upon bushmeat's erroneous status as a "main" vector, its production and consumption should immediately end: "The Ebola outbreak [was] an opportunity to clamp down on a practice which both causes disease outbreaks and empties forests of wildlife" (para. 4, emphasis mine).

To be clear, forests worldwide are in dire straits due to unsustainable environmental practices ranging from industrial logging to illegal poaching. However, while deforestation, ground clearing, and poaching absolutely amplify habitat loss and resultant zoonotic contacts between species, this fact served as a pretext for a dubious discursive trope deriding African ambivalence towards animal life and environmental sustainability - a trope contingent upon the naturalization and normalization of carnistic colonialism.

That bushmeat can and does make its way out of rural communities and into urban centers is not under debate. However, according to the Center for International Forestry Research (CIFOR,) over ten million Africans rely on bushmeat for over $80 \%$ of their protein intake-far from a privileged few (Cooney, 2014). Anti-bushmeat rhetors centering conservation argued that bushmeat was not as much a subsistence diet for disenfranchised rural populations as an expensive luxury for urban elites. Two years prior to the Ebola outbreak, One
Green Planet was already warning that "Our appetites for unnecessary "exotic meats," especially those which are endangered, must be curbed." The author further protested:

The meat of these endangered animals does not feed starving people. It is bought and sold at incredibly high prices as a luxury item by urban Africa, as well as transported internationally and sold on black markets. In some cities, a small piece of chimpanzee meat can fetch the same price as an entire cow. (McArthur, 2012, para. 5).

2014 anti-bushmeat rhetoric functioned similarly, framing bushmeat as an exotic treat falsely represented by cultural activists as necessary nutrition for the poor. Conservationists worried about the "commercialisation of bushmeat" wherein "Animals are hunted for food in rural areas, but also to sate the desire for wild meat in the more populous urban centres" (Bryce, 2015, para. 8). Bushmeat was little more than an illegal indulgence, a "secret market" that had "hitherto been defended on cultural grounds" (Malone, 2014, para. 7). It was simultaneously "a luxury" and "a deadly threat" (Flynn and Scutti, 2014, para. 7). That threat was not only the spread of Ebola, but the gradual elimination of Africa's endangered species for little reason other than Africans' moral ambivalences.

Some rhetors portrayed an out-of-control bushmeat trade as resultant from unnatural interactions between human civilization and pristine African wilderness. They accurately noted how intensive deforestation via over-logging and mining propelled bats and other species out of their isolated forest habitats and into close contact with humans. However, anti-environmental business policies aside, for many writers the greater concern was the brutal, callous Africans hunting wildlife without regard for ecological welfare: "the [bushmeat] trade is horrifically cruel. Wild animals should be left in the wild, for all our sakes" (Williams, 2014, para. 8). The Guardian concurred: "The answer seems like a given. Without bushmeat, infection is almost entirely cut out of the picture, and vulnerable forest species are shielded from hunters." (Bryce, 2015, para. 4). And, since natives could not be trusted to stop bushmeat hunting on their own, New Scientist appealed to multinational corporations, particularly airlines, to "rapidly and unilaterally make a huge difference" by ceasing transportation of wildlife, alive or dead (Williams, 2014, para. 7).

In advocating for permanent bans on the bushmeat trade, Ebola's "silver lining" was that some countries' bushmeat "crackdown" could turn into a long-term conservation move that might "give dwindling forest species room to recover". (Bryce, 2015, para. 2). Granted, not all bushmeat animals were created equal. Writers mostly reserved their animal welfare frames for charismatic megafauna like great apes. The Guardian encapsulated how "endangered species" became a carefully coded phrase for those specific animals deemed culturally valuable: "Bushmeat has a bad name for a good reason: it threatens already endangered species, and strips forests of their keystone species, with untold effects on ecosystem biodiversity as a whole" (para. 7). Even while acknowledging their relatively marginal presence in the African bushmeat trade, the author mourned: "Great apes comprise a small percentage of the bushmeat trade in 
Africa-5\%, or less-but these highly vulnerable animals are still illegally hunted, and even a small dent in their already fragile populations can have a devastating impact" (para. 7). Similar media narratives highlighted charistmatic megafauna such as elephants and lion under the banner of the West African bushmeat trade-again, despite their marginal presence compared to the small, lesser-known, and ecologically "resilient" animals most typically slaughtered: animals like porcupines, pouched rate and duikers (Vander Velde, 2014).

Again, my critique aims neither to minimize global ecological concerns impacted by unregulated hunting nor to advocate for the wanton slaughter of animals provided they are not endangered. However, the conservation-themed discourses emerging in the 2014 Ebola epidemic reveal concerning hegemonic ideologies guiding the valuation of certain charismatic species over mere "vermin" subsequent desires to protect those special animals from morally ambiguous natives. That one conservative editorial outlet claimed "Bush meat is a foreign concept to most Americans" (Chastain, 2014, para. 3) is a misnomer: big game hunting is, after all, a standard activity for wealthy Westerners traveling to Africa, including former U.S. President Donald Trump's elder sons. Considering the popularity of hunting "game" in Western countries-the outcry over hunting wild animals native to the African continent is ironic. Indeed, concern over intensive hunting seems restricted to practices "over there" reflects differential cultural standards guiding which animals "matter" and which people should be allowed to hunt them-a standard teeming with colonial history.

Colonial logics have historically painted Africans as horrifically cruel to animal beings in contrast to the more "humane" practices of Westerners:

According to whites-missionaries, settlers, and colonial officials alike-Africans acted with wanton cruelty to dumb beasts. Africans who regularly inflicted unnecessary suffering on animals felt no empathy for their victims. In contrast, Europeans, modern bourgeois individuals, abhorred suffering. Or rather, they abhorred unnecessary suffering. (Shadle, 2012, p. 1098).

While both Westerners and Africans hunted for food and other materials, colonial European hunting ethics maintained that animal suffering resulting in positive results was not cruel. Brutalization that served no logical purpose-like barbaric bushmen's spear-hunting--was inhumane, antithesis to civilized society, and in need of moral intervention by colonists (Shadle, 2012). Colonial intervention strategies included banning traditional hunting tools while simultaneously banning natives from owning or discharging firearms (the only civilized way to hunt), thus restricting the hunting of wild "game" (read: bushmeat) to white, moneyed men.

Understanding colonial histories of "humane" hunting and "positive" animal suffering elucidates the problematics of conservation argumentation during the 2014 Ebola outbreak. Different categorizations of animality evoke different affective responses in humans when confronted with an animal's death and consumption (Bratanova, Loughnan and Bastian, 2011). "Food animal" is conceptual frame that makes salient particular attributes of an animal, such as its tastiness, at the expense of others, like its capacity to suffer. Thus, when people confront the "meat" of creatures not commonly classified as "food" animals, they are more likely to "picture the living animal from which it came, and we tend to feel disgusted at the notion of eating it" (Joy, 2011, p. 15). When confronted with the consumption of "vermin" (like Emile Ouamouno's bat), people's affective responses are compounded via "pestilence discourses" (Knight, 2000)—frames depicting certain animals as dirty, criminal, numerous, and killable. These frames manifested as empathic "sentiment with powerful political valences” (McGovern, 2014, para. 7).

While the suffering involved in any animal's death for consumption is undeniable, to frame only certain killings as "grotesque," "inhumane," or "unnecessary" conveniently ignores the cruelties involved in industrialized meat production and Western animal consumption practices. Consider American practices of de-beaking chickens and taildocking pigs, or force-feeding geese for foie gras, or intensive confinement of animals leading to psychotic breaks, or recorded instances of slaughterhouse employees beating "downed" animals-all despite readily available alternatives such as legumes, nuts, vitamins, plant-based fibers, governmentallysubsidized soy, etc.

For those who would label African bushmeat as particularly unethical because bushmeat animals are endangered, again note how carnistic colonialism renders invisible the species degradation involved in industrialized agriculture. As the World Animal Foundation (WAF) has noted:

The animal agriculture industry is killing our environment and putting every species on this planet at risk of extinction. The animal agriculture industry's pollution of our air, water and land, along with deforestation and soil degradation, all contribute to habitat loss and species extinction. Like a domino effect, a multitude of aspects is leading to the destruction of Earth's biodiversity. (WAF, 2017, para. 8).

Even if chimpanzees and other endangered beings are, for some reason, of greater moral importance than other animals due to their diminishing numbers, this rationale is not enough to explain cognitive dissonances towards transnational animal consumption and destruction. The extreme deforestation that has put bushmeat hunters and endangered fauna ever closer together is not a result of specifically African moral deficiencies. Multinational logging and mining industries also encourage these unsustainable environmental practices, as does international demand for coffee and diamonds, as has the search for palm oil (Biello, 2008; Casey and Elias, 2015).

Portrayals of conservation as Ebola's "silver lining" thus represented a well-intentioned yet colonial, carnistic discourse. In aiming to "save Africa from Africans" (Nelson, 2003), rhetors seemingly in favor of biodiversity and animal welfare rendered invisible the Western hunting, farming, and extraction practices culpable in the destruction of African wildlife, wildlife writ large, and Ebola's spread.

\section{Development}

Amidst the 2014 Ebola epidemic emerged a third controversial discourse: development. 
Development discourses frequently centered Western standards of privatized agriculture. A notable argumentative trope emerged, arguing that African economic and health development agendas hinged on countries' willingness to adopt capitalistic livestock markets. This discourse invoked carnistic colonialism by dubbing industrialized agriculture as natural, normal, and necessary for the progress of humankind.

Rhetors argued that for Ebola-stricken communities, international agricultural development meant a shift from bushmeat as a source of protein to a Western-style livestock market economy. In other words, agricultural development should comport to colonial, carnist standards previously set forth by "developed" communities. The Ecologist condemned the "often romanticized view of native peoples as conservationists," as "this situation is more to do with their limited technology and small populations relative to their environment" (Young, 2014, para. 15). While the native-asecological-panacea argument is problematic (see Krech, 2000), this particular author argued that the African bushmeat trade continued to flourish because "judges in these countries where the hunting takes place often, naively, believe the hunter's pleas of poverty and just "smack them on the wrists"'” (para. 19). Such claims, he argued, were facile, as hunting-and-gathering lifestyles were "much more expensive than buying chicken from the supermarket" (para. 20). If African peoples really wanted to make a decent living through food production, they needed to acknowledge "Humans spent the last few years breeding chickens, cows, and pigs for a reason: they make a nicer, cheaper, and less dangerous dinner" (para. 20). Still other writers concurred, arguing that rural Africans, "despite the evidence ... have expressed panic at the idea of changing their lifestyles and creating a livestock market" (Chastain, 2014, para. 1).

The United Nations (UN) adopted a similar argument. Chief veterinary officer Juan Lubroth suggested that discouraging bushmeat hunting depending upon shifts to livestock markets: "We recognize [sic] the importance that bush meat has to quality nutrition ... Can we have a more development agenda where we could have poultry production, sheep, goats, pigs ... so that there is no undue encroachment into the forest for hunting?" (qtd. in Chastain, 2014, para. 12-13). The United States Development Programme (UNDP) for Sierra Leone chastised existing arguments that African development might occur through "sustainable" bushmeat hunting, publishing a report stating: "evidence from other African countries shows that the domestication and commercial farming of wildlife can protect livelihoods, help meet the demand for animal protein and benefit local ecosystems" (UNDP, 2015, p. 2). Its steps for developing Sierra Leone's infrastructure included "Introducing alternative sources of animal protein, such as poultry or pork production, especially among communities reliant on bushmeat" as well as promoting "Commercial farming of wildlife species and nationwide marketing" (p. 2).

"Development" writ large is a troublesome ideological triggerbutton often serving as a catch-all term for industrialization and capitalist transition. Within the context of food production and consumption, however, entities like the World Bank consider international agricultural development as essential for "spurring growth, overcoming poverty, and enhancing food security" vis-àvis "a sharp productivity increase ... by diversifying into laborintensive, high-value agriculture" in order to "help developing countries address climate change; and overcome looming health pandemics for plants, animals, and humans" (World Bank, 2008). The modernization of food production through ever-industrialized agriculture in "developed" nations has undoubtedly provided many humans access to a predictable, diverse, and abundant food supply (Collier and Lakoff, 2008). However, ownership of domestic crops and animals is often associated with distinctions between civilization and barbarism, wherein agriculture represents questions about what it means to be human (Cudworth and Hobden, 2014). High-tech agriculture can act as metaphor for a "standard of civilization," primarily based on assumptions that humankind and nature must be kept separate. Within this set of standards, "those societies that are perceived as being most detached [are] regarded as the most civilized, while those that are mired in nature are perceived as in some ways less civilized" (Cudworth and Hobden, 2014, p. 747).

Thus, at the bottom of this sliding scale of civility are huntergatherers, the barely-humans who "were either to brought within these forms of society, or would naturally die or be exterminated" (p. 752). Managing exotic, extreme forms of nature in colonized (or "post" colonized) territories has traditionally been a mechanism for "civilizing" both the colonized. A part of this process includes mandatory transitions from hunters for farmers, from wild fauna to domesticated livestock/mono-cropped plants. Indeed, "current narratives of progress in agricultural production are linked to the development of intensive stock-raising systems throughout parts of Africa" (p. 760). Therefore, this transition is not natural, normal, and necessary, but colonial and carnistic.

Some predict that even if Africa converted to industrial agribusiness, resultant "development" (in the form of increased personal wealth for citizens) would be limited. High-tech agriculture in "third-world" countries historically tends to strengthen control of elites and perpetuate social inequality-for instance, by maintaining moneyed men's control of the economy (Shiva, 1993; Plumwood, 2002). Pushing against colonial, carnist standards of development requires questioning the thesis that industrial agriculture is an indubitably more civilized, sustainable, and economically viable mode of food production. Some are already doing just that, asserting that banning the bushmeat trade would do more harm than good to rural African peoples. The Independent reported that bushmeat represents a quarter of meat consumption in Liberia's rural areas. During increased restrictions during the Ebola epidemic, women traders in cities and towns "lost the empowerment that comes with being employed" experienced "nutritional disadvantage and rising food insecurity" (Bryce, 2015, para. 4). The consequences of $1,000+$ traders, particularly women, losing their jobs and the income that sent their children to school were "the more complex aspect of the argument that's often left out, because it's easier to fixate on bushmeat" (para. 13). CIFOR concurred, equating the "just switch to livestock" narrative to saying "let them eat cake" to vulnerable populations: "Achieving sustainable harvest of bushmeat is therefore a necessity, and by far the best available option" (para. 11). 
Analyses of the social and economic consequences of shift to industrial agriculture need not be restricted to Africa. Even in purportedly "developed" societies, increased water and air pollution from animal agribusiness further separates the rich from the poor as the means for a healthy life are privatized. Health and nutrition become "the privilege of those who can afford to pay for them ... The losers will be (and in many places already are) those ... without market power" (Plumwood, 2002, pp. 13-14). Environmental racism thrives in countries like the United States, with industrial agribusiness centers disproportionately polluting poor and disenfranchised communities (Zimring, 2017).

Intensive livestock industries are, according to the United Nations, "one of the top two or three most significant contributors to the most serious environmental problems, at every scale, from local to global" (qtd. in Joy, 2011, p. 86). The world's largest source of water pollution is animal agriculture. The more intensive the production, the worse the pollution. Water is contaminated by antibiotics, hormones, chemicals, animal waste, erosion-caused sediment, fertilizer, and feed crop pesticides. $55 \%$ of soil erosion in the United States has resulted from animal agribusiness, as has $37 \%$ of insect- and animal-killing pesticides. $70 \%$ of the Amazon's forestland has been completely converted to livestock pastures (Joy, 2011). According to CIFOR, inhabitants of entire Africa's Congo Basin consume five million tons of bushmeat per year, nearly equal to the annual cattle production of the European Union. After a decade of studying the bushmeat trade, CIFOR concluded that producing the same amount of meat through cattle ranching in the basin would require a full twenty-five million hectares of forest to be converted into farmland, about the size of Great Britain (Cooney, 2014).

Furthermore, a conversion to industrialized agriculture would hardly "civilize" the agricultural workforce. Injuries, psychological distress, and disease are endemic in industrialized slaughter industries. For instance, employees in American abattoirs, many of whom are undocumented immigrants and/or people of color, work in unsanitary conditions that expose them to noxious gases, concentrated waste, and the same blood and guts that Ebola commentators worried would spread disease. These employees have considerably higher rates of zoonoses than the rest of the population, despite the industry's supposedly superior health and safety standards compared to bushmeat hunting. Employees additionally demonstrate high rates of respiratory disease, reproductive dysfunction, seizures, and neurological dysfunction (Muller, 2018). In essence, claims that hyper-capitalist, high-tech, industrial agriculture is more sanitary and more protective to workers and citizens conceals how corporate agribusiness consistently avoids regulation, thus perpetuating a thoroughly uncivilized system of food production in the name of colonial and carnistic "progress". This discursive trope not only represents mass-mediated overconfidence in the benefits of industrialized agriculture, but also demonstrates the continued silencing of Other potentialities for "knowing" and "doing" food production and consumption, a phenomenon that Shiva (1993) condemned as "monocultures of the mind."

Anti-bushmeat discourses centering development, emphasizing that Africa and Africans might be "saved" from
Ebola by replacing traditional hunting practices with corporatized farming practices. Rhetors' simplistic conception of a hunter-gatherer/agribusiness dichotomy when dealing with issues of global food security, ecological destruction, and disease management, carried "the imperialist baggage of a civilizing mission" (Cudworth and Hobden, 2014, p. 761). Development frames did little more than continue a long-standing colonial logic concerned with separating civilized humans from wild, undomesticated nature.

\section{CONCLUDING REMARKS}

Assessing how bushmeat narratives functioned during the 2014 Ebola outbreak elucidates the connections between food, flesh, and (post)colonial politics. While the consumption of nondomesticated animal flesh likely played at least some role in Ebola's spread, Western rhetors' bushmeat-centered outbreak narratives demonstrated less of a concern with accurate epidemiology and more of a concern with the grotesqueness and deviance of non-Western meat consumption. Writers ranging from expert to editorialist perpetuated standards of carnistic colonialism-a term future scholars might use to further understanding of the relationships between colonialism, racism, speciesism, and contemporary cultural dynamics of biosecurity, conservation, and international development.

Pinpointing instances of carnistic colonialism demands defamiliarizing and critiquing meat as a shifting construct and flesh consumption as a global practice. Fighting it demands the constant critique of what/who "meat" is and what the future of food could be. Critiquing carnistic colonialism must go beyond simple castigations some foreign Other's unsavory foodstuffs. Rather, critics should engage in a genuine (and very uncomfortable) evaluations of the food production and consumption practices in which they themselves are most complicit. For some people, these practices will have to include bushmeat. Others need look no further than the factory-farmed cow flesh waiting in their freezer.

Meat is not a clear or stable concept, yet during pandemic threats, normative Western standards of meat consumption are elevated to maintain anthropocentric, ethnocentric hierarchies through acts such as animal naming, raising, slaughtering, cooking, and consumption. Carnistic colonialism thus privileges the human over the animal, certain humans over other humans, and certain animals over other animals. These valuations are cloaked in debates over edibility, animal cruelty, economics, and hygiene. While the 2014 Ebola outbreak is an exemplar of this hegemonic discourse, it was not the first and will not be the last. Reminiscent of anti-bat meat discourses during the 2003 SARS epidemic and current anti-dog meat protests in response to the Chinese Yulin Dog Meat Festival, the 2014-16 consumption of particular animals' (vermin and/or precious) was deemed unnecessary and immoral, and thus in need of mass Western intervention. Recent depictions of Chinese "wet markets" have been disproportionately tied to the current COVID-19 pandemic in a manner hauntingly similar to 2014 (Shepherd, 2020). 
To be clear, I do not argue that eating bushmeat is in all or any circumstances ethical or desirable. As a Western rhetor raised and embedded in Western consumption systems, that is not how I view my scholarly duty. Rather, I offer carnistic colonialism a needed counter-criticism of hyper-capitalist, industrial standards of meat consumption so often offered as the pinnacle of civilized society. I do not insist that no action should be taken locally, nationally, or internationally to curb unsustainable food practices-hunting-based or otherwise. Indeed, given the existential threat posed by zoonotic illnesses and the ongoing terror of the COVID-19 pandemic, it is clear that the more-than-human world is in desperate need of moral and material change. However, who precisely must change and in what capacity is consistently glossed over through the vilification of Others via discourses like carnistic colonialism.

The ultimate conclusion of this essay is this: Understanding and invoking anti-speciesism in conjunction with a decolonial telos uncovers how Western rhetors strategically minimize their own complicity in the existential threat posed by zoonotic diseases like Ebola and COVID-19. Omnipresent in the rhetoric that is carnistic colonialism are 1) the colonial drive to to demonize the (post)colonial Other; 2 ) the moral elevation of Western standards of meat production and consumption; and 3)

\section{REFERENCES}

Abram, D. (1996). The Spell of the Sensuous: Perception and Language in a MoreThan-Human World. New York: Vintage.

Adams, C. (1994). The Sexual Politics of Meat: A Feminist-Vegan Critical Theory. 1st Edn. Bloomsbury Publishing. doi:10.5040/9781501312861

Adams, C. J. (1997). "Mad Cow" Disease and the Animal Industrial Complex, Organization \& Environment. Organ. Environ. 10 (1), 26-51. doi:10.1177/ 0921810697101007

Adams, C. J. (2006). An Animal Manifesto Gender, Identity, and Vegan-Feminism in the Twenty-First Century. Parallax 12 (1), 120-128. doi:10.1080/ 13534640500448791

Anderson, W. (1995). Excremental Colonialism: Public Health and the Poetics of Pollution. Crit. Inq. 21 (3), 640-669. doi:10.1086/448767

Anderson, W. (1999). Perception of Disease and its Meanings. Lancet 354, 49. doi:10.1016/s0140-6736(99)90392-6

Belcourt, B.-R. (2015). Animal Bodies, Colonial Subjects: (Re)Locating Animality in Decolonial Thought. Societies 5 (1), 1-11. doi:10.3390/soc5010001

Benton, A., and Dionne, K. Y. (2015). International Political Economy and the 2014 West African Ebola Outbreak. Afr. Stud. Rev. 58 (1), 223-236. doi:10.1017/asr.2015.11

Best, S., Nocella, A. J., Kahn, R., Gigliotti, C., and Kemmerer, L. (2007). Introducing Critical Animal Studies. J. Crit. Anim. Stud. 5 (1), 4-5.

Biello, D. (2008). Satellite's Eye View of an Africa despoiled. Sci. Am. Available at: https:/www.scientificamerican.com/article/satellites-eye-view-of-africa/ (Accessed April 1, 2021).

Bratanova, B., Loughnan, S., and Bastian, B. (2011). The Effect of Categorization as Food on the Perceived Moral Standing of Animals. Appetite 57 (1), 193-196. doi:10.1016/j.appet.2011.04.020

Bryce, E. (2015). Is it Time to Bring Back bush Meat? The Guardian. Available at: https://www.theguardian.com/environment/world-on-a-plate/2015/jul/10/ is-it-time-to-bring-back-bushmeat.

Casey, M., and Elias, N. (2015). Palm Oil Plantations Threaten African primates. Scientific Am. Available at: https://www.scientificamerican.com/article/palmoilplantations-threaten-african-primates/ (Accessed April 1, 2021).

Center for Disease Control (2014). Facts about bush Meat and Ebola. CDC Stacks: Public Health Publications. the fallacious and ahistorical implication that the Westernization of non-Western food systems would be a "magic bullet" solution to issues of public health, conservation, and international development. Global food production and consumption practices need to change and there is no doubt about that. However, the solutions posed through carnistic colonialism are akin to patching a stab wound with a bandage. Without a serious reconsideration of speciesism, meat production and consumption, and the global food industry's historical/ contemporary relationship with colonial politics, the world only has a matter of time before it bleeds out.

\section{DATA AVAILABILITY STATEMENT}

The original contributions presented in the study are included in the article/Supplementary Material, further inquiries can be directed to the corresponding author.

\section{AUTHOR CONTRIBUTIONS}

The author confirms being the sole contributor of this work and has approved it for publication.

Chastain, M. (2014). UN: Ebola Outbreak Likely Caused by bushmeat. Breitbart. Available at: http://www.breitbart.com/national-security/2014/08/06/un-ebolaoutbreak-likely-caused-by-bushmeat/ (Accessed April 1, 2021).

Collier, S., and Lakoff, A. (2008). "Problem of Securing health,"in Biosecurity interventions: global health and security in question. Editor A. Lakoff (New York: Columbia University Press), pp. 7-32.

Condit, C. (2015). The spread of ebola: How the world health organization's rhetoric contributed to virus transmission. Mètode 6, 121-127. doi:10.7203/ metode.6.4403

Cooney, D. (2014). Ebola and bush Meat in Africa: Q\&A with Leading researcher. Center Int. Forestry Res. [blog post]. Available at: http://blog.cifor.org/23924/ebolaand-bushmeat-in-africa-qa-with-leading-researcher?ga =1.239419523.1260789577. 1413303503\#.VD1VOrDF_y0 (Accessed April 1, 2021).

Crenshaw, K. (1990). Mapping the margins: Intersectionality, identity politics, and violence against women of color. Stanford Law Review 43, 1241-1299.

Cudworth, E., and Hobden, S. (2014). Civilisation and the Domination of the Animal. Millennium 42 (3), 746-766.doi:10.1177/0305829814540355

Curtin, D. (1991). Toward an Ecological Ethic of Care. Hypatia 6 (1), 60-74.doi:10. 1111/j.1527-2001.1991.tb00209.x

Davidovitch, N., and Zalashik, R. (2006). Medical Borders: Historical, Political, and Cultural Analyses. Sci. Context 19 (3), 309-316. doi:10.1017/s0269889706000949

Everard, M., Johnston, P., Santillo, D., and Staddon, C. (2020). The Role of Ecosystems in Mitigation and Management of Covid-19 and Other Zoonoses. Environ. Sci. Policy 111, 7-17. doi:10.1016/j.envsci.2020.05.017

Flynn, G., and Scutti, S. (2014). Smuggled Bush Meat is Ebola's Back Door to America. Newsweek. Available at:http://www.newsweek.com/2014/08/29/smuggled-bushmeatebolas-back-door-america-265668.html.doi:10.1093/obo/9780199828340-0150

Gaard, G. C. (2001). Tools for a Cross-Cultural Feminist Ethics: Exploring Ethical Contexts and Contents in the Makah Whale Hunt. Hypatia 16 (1), 1-26. doi:10. 1353/hyp.2001.0006

Gaard, G. C. (2002). Vegetarian Ecofeminism: A Review Essay. Women Studies 23 (3), 117-146. doi:10.1353/fro.2003.0006

Greger, M. (2011). Transgenesis in Animal Agriculture and Zoonotic Disease Resistance. CAB Reviews 6 (41), 1-6. doi:10.1079/pavsnnr20116041

Harper, A. B. (2011). "Vegans of Color, Racialized Embodiment, and Problematics of the "Exotic","in Cultivating Food justice: Race, Class, and Sustainability. Boston, MA: MIT Press, 221-238. 
Hasian, M., and Muller, S. M. (2016). Post-Conflict Peace Initiatives, British Mau Mau Compensation, and the Mastering of Colonial Pasts. J. Multicultural Discourses 11 (2), 164-180. doi:10.1080/17447143.2016.1182535

Hasian, M. (2016). Representing Ebola: Culture, Law, and Public Discourse about the 2013 - 2015 West African Ebola Outbreak. Lanham, MD: Rowman and Littlefield.

Hasian, M. (2001). Rhetorical Studies and the Future of Postcolonial Theories and Practices. Rhetoric Rev. 20 (1/2), 22-28.

Hinchliffe, S., Allen, J., Lavau, S., Bingham, N., and Carter, S. (2013). Biosecurity and the Topologies of Infected Life: From Borderlines to Borderlands. Trans. Inst. Br. Geogr. 38 (4), 531-543. doi:10.1111/j.1475-5661.2012.00538.x

Hogenboom, M. (2014). Ebola: Is bush Meat behind the Outbreak? BBC News. Available at: http://www.bbc.com/news/health-29604204.

Huff, A., and Winnebah, T. (2015). Ebola, Politics and Ecology: Beyond the "Outbreak Narrative". Institute of Development Studies,.Practice Paper in Brief 20. 1-4.

Hunt, K. P. (2014). "It's More Than Planting Trees, It's Planting Ideas": Ecofeminist Praxis in the Green Belt Movement. South. Commun. J. 79 (3), 235-249. doi:10.1080/1041794x.2014.890245

Joy, M. (2011). Why We Love Dogs, Eat Pigs, and Wear Cows: An Introduction to Carnism. Newburyport, MA: Conari Press.

Kim, C. J. (2015). Dangerous Crossings. New York, NY: Cambridge University Press. doi:10.1017/cbo9781107045392

Knight, W. A. (2000). "Introduction," in Natural Enemies: People-Wildlife Conflicts in Anthropological Perspective. Editor J. Knight (Sussex, UK: Psychology Press), 1-12. doi:10.1057/9780333984420_1

Ko, A., and Ko, S. (2017). Aphro-ism: Essays on Pop Culture, Feminism, and Black Veganism from Two sisters. New York, NY: Lantern Books.

Krech, S. (2000). The Ecological Indian: Myth and History. WW Norton \& Company.

Landers, T. F., Cohen, B., Wittum, T. E., and Larson, E. L. (2012). A Review of Antibiotic Use in Food Animals: Perspective, Policy, and Potential. Public Health Rep. 127 (1), 4-22. doi:10.1177/003335491212700103

Malone, A. (2014). Secret trade in monkey meat that could unleash Ebola in UK. Daily Mail. Available at: https://www.dailymail.co.uk/news/article-2713707/ Secret-trade-monkey-meat-unleash-Ebola-UK-How-appetite-African-delicaciesBritish-markets-stalls-spread-killer-virus.html (Accessed August 1, 2014)

McArthur, J. (2012). The bush meat trade: Not just Africa's Problem. One Green Planet Available at https://www.onegreenplanet.org/animalsandnature/thebush-meat-trade-not-just-africas-problem/ (Accessed October 26, 2011)

McGee, M. C. (1980). The "Ideograph": A Link between Rhetoric and Ideology. Speech 66 (1), 1-16. doi:10.1080/00335638009383499

McGovern, M. (2014). Bushmeat and the Politics of disgust. Cultural Anthropol. Available at:. https://culanth.org/fieldsights/588-bushmeat-and-the-politics-ofdisgust (Accessed April 1, 2021).

McKerrow, R. E. (1989). Critical Rhetoric: Theory and Praxis. Commun. Monogr. 56 (2), 91-111. doi:10.1080/03637758909390253

Mignolo, W. (2011). Epistemic Disobedience and the Decolonial Option: A Manifesto. Transmodernity 1 (2), 44-46.

Montford, K. S., and Taylor, C. (2020). Colonialism and Animality: Anti-colonial Perspectives in Critical Animal Studies. New York, NY: Lexington Books.

Muller, S. M. (2018). Zombification, Social Death, and the Slaughterhouse: U.S. Industrial Practices of Livestock Slaughter. Am. Stud. 57 (3), 81-101. doi:10. 1353/ams.2018.0048

Nelson, R. (2003). Environmental Colonialism:"Saving" Africa from Africans. Independent Rev. 8 (1), 65-86.

A. J. Nocella, II, R. J. White, and E. Cudworth (2015). Anarchism and Animal Liberation: Essays on Complementary Elements of Total Liberation. McFarland.

Plumwood, V. (2002). Feminism and the Mastery of Nature. New York, NY: Routledge. doi:10.4324/9780203006757

Quijano, A. (2000). Coloniality of Power and Eurocentrism in Latin America. Int.Sociol. Ogyernational. 15 (2), 215-232. doi:10.1177/0268580900015002005

Richardson, J. (2012). Deadly African Ebola Virus Linked to bush meat. Food Saf. News. Available at: http://www.foodsafetynews.com/2012/09/deadly-africanebola-virus-linked-to-bushmeat/\#.WK3o73-Hglp (Accessed April 1, 2021).

Sastry, S., and Dutta, M. J. (2017). Health Communication in the Time of Ebola: A Culture-Centered Interrogation. J. Health Commun. 22 (Suppl. 1), 10-14. doi:10.1080/10810730.2016.1216205
Shadle, B. L. (2012). Cruelty and Empathy, Animals and Race, in Colonial Kenya. J. Soc. Hist. 45 (4), 1097-1116. doi:10.1093/jsh/shr152

Shepherd, K. (2020). John Cornyn Criticized Chinese for Eating Snakes. He Forgot about the Rattlesnake Roundups in Texas. Wash. Post. Available at: https://www. washingtonpost.com/nation/2020/03/19/coronavirus-china-cornyn-blame/ (Accessed April 1, 2021).

Shiva, V. (1993). Monocultures of the Mind: Perspectives on Biodiversity and Biotechnology. New York, NY: Palgrave Macmillan.doi:10.5040/ 9781350219786.ch-011

Shome, R., and Hegde, R. S. (2002). Postcolonial Approaches to Communication: Charting the Terrain, Engaging the Intersections. Commun. Theory. 12, 249-270. doi:10.1111/j.1468-2885.2002.tb00269.x

Singer, P. (1975). Animal Liberation. New York: Random House.

United Nationals Development Programme (2015). Ebola Recovery in Sierra Leone. Available at: http://www.sl.undp.org/content/sierraleone/en/home/library/crisis prevention_and_recovery/undp-sierra-leone-ebola-recovery-strategy-and-actionplan-/ (Accessed April 1, 2021).

Vander Velde, B. (2014). 10 Things You Didn't Know about Bushmeat in Africa. Center Int. Forestry Res. [blog post]. Available at: http://blog.cifor.org/23954/10things-you-didnt-know-about-bushmeat-in-africa?fnl=en (Accessed April 1, 2021).

Wander, P. (1984). The Third Persona: An Ideological Turn in Rhetorical Theory. Commun. Stud. 35 (4), 197-216. doi:10.1080/10510978409368190

Wanzer, D. (2012). Delinking Rhetoric, or Revisiting McGee's Fragmentation Thesis through Decoloniality. Rhetoric Public Aff. 15 (4), 647-657. doi:10.2307/ 41940627

Wilkinson, A., and Leach, M. (2015). Briefing: Ebola-Myths, Realities, and Structural Violence. African Aff. 114 (454), 136-148. doi:10.1093/afraf/adu080

Williams, T. (2014). Ebola's Silver Lining: We Can Clamp Down on Bushmeat. New Scientist. Available at: https://www.newscientist.com/article/mg22329850. 300-ebolas-silver-lining-we-can-clamp-down-on-bushmeat/\#.VD1SDbDF_y0 (Accessed April 1, 2021).

World Animal Foundation (2017). Animal Agriculture Causing Animal Extinction. Available at: http://www.worldanimalfoundation.org/articles/ article/8949042/186425.htm (Accessed April 1, 2021).

World Bank (2008). Agriculture for Development. Available at: https:// siteresources.worldbank.org/INTWDR2008/Resources/WDR_00_book.pdf (Accessed April 1, 2021).

World Health Organization. (2014). Information Note: Ebola and Food Safety. Available at: https://www.who.int/csr/disease/ebola/note-ebola-food-safety/en/ (Accessed April 1, 2021).

World Health Organization. (2016). Situation Report: Ebola Virus Disease. Available at: http://apps.who.int/iris/bitstream/10665/208883/1/ebolasitrep_ 10Jun2016_eng.pdf (Accessed April 1, 2021).

World Health Organization (2021). Ebola Virus Disease. Available at: https://www. who.int/health-topics/ebola\#tab=tab_1 (Accessed April 1, 2021).

Wright, L. (2017). Introducing Vegan Studies. ISLE: Interdiscip. Stud. Lit. Environ. 24 (4), 727-736. doi:10.1093/isle/isx070

Wynter, S. (2003). Unsettling the coloniality of being/power/truth/freedom: Towards the human, after man, its overrepresentation-An argument. CR: The new centennial review 3 (3), 257-337.

Young, R. (2014). Take Bushmeat off the Menu before Humans are Served Another Ebola. Ecologist. Available at: http://www.theecologist.org/blogs_and comments/commentators/2594108/take_bushmeat_off_the_menu_before _ humans_are_served_another_ebola.html (Accessed April 1, 2021).

Zimring, C. A. (2017). Clean and white: A History of Environmental Racism in the United States. New York, NY: NYU Press.

Conflict of Interest: The author declares that the research was conducted in the absence of any commercial or financial relationships that could be construed as a potential conflict of interest.

Copyright (C) 2021 Muller. This is an open-access article distributed under the terms of the Creative Commons Attribution License (CC BY). The use, distribution or reproduction in other forums is permitted, provided the original author(s) and the copyright owner(s) are credited and that the original publication in this journal is cited, in accordance with accepted academic practice. No use, distribution or reproduction is permitted which does not comply with these terms. 